\title{
Immunofluorescent localization of secretin in the canine duodenum
}

\author{
JUlia M. POLAK, S. Bloom, I. COUlling, AND A. G. E. PEARSE \\ From the Royal Postgraduate Medical School, Hammersmith Hospital, and the Institute of Clinical Research, \\ Middlesex Hospital, London
}

SUMMARY The endocrine polypeptide (APUD) cells responsible for the production and storage of secretin have been demonstrated, in canine duodenum, by the application of an indirect immunofluorescence technique, using anti-pure porcine secretin, to carbodiimide-fixed cryostat sections. The cells are identified, by the use of parallel cytochemical and ultrastructural preparations, as the small granular $\mathrm{S}$ cells. These are essentially restricted to the transitional zone of the duodenal mucosa, with whose lumen their apical projections probably always make contact. There is no need to alter the title of the cells since $\mathrm{S}$ can now stand for secretin instead of for small.

The discovery of secretin by Bayliss and Starling (1902) introduced the concept of hormonal regulation of digestive processes, and its main action was found to be the stimulation of alkaline secretion by the pancreas. After more than half a century the hormone was successfully identified and isolated by Jorpes and Mutt (1961a and b). Subsequently (Mutt, Magnusson, Jorpes, and Dahl, 1965) its structure was determined and it was shown to be an heptacosapeptide degradable by trypsin into five peptides whose amino-acid compositions were determined. In a more recent paper Mutt, Jorpes, and Magnusson (1970) reported the complete amino-acid sequence of porcine secretin and they showed that 14 of its 27 amino acids occur in the same position as in porcine glucagon.

\section{Distribution of the Hormone}

Studies on the distribution of secretin in the gastrointestinal tract have been made either by measuring the pancreatic response to localized intestinal stimuli, or by assaying its response to extracts of specific regions of the intestine. The results obtained by several groups of workers indicated that high levels of secretin are found only in the first portions of the small intestine. Low levels are invariably found in the pylorus and in the more distal parts of the small intestine (Komarov, 1942; MunchPetersen, Rönnow, and Uvnäs, 1944; Friedman and King, 1950; Grossman, 1958). Although Mellanby (1926) had already suggested that the distribution of Received for publication 27 May 1971. secretin might vary from species to species, the localization of this hormone appears to be much less variable than that of most other gastrointestinal hormones.

The distribution of enterochromaffin cells in the intestinal mucosa appeared to Gillman (1942) to be comparable to that of extractable secretin, and indeed some investigators (Parat, 1924; Wermel and Kacharova, 1948) suggested that these cells were the source of secretin. Cordier (1926), however, found that enterochromaffin granules were not extractable with acid and hence he considered Parat's hypothesis untenable.

Fresh frozen sections of canine duodenal mucosa, cut at different levels parallel to the long axis of the intestine, were assayed for their effect on pancreatic secretion by Krawitt, Zimmermann, and Clifton (1966). These authors concluded that secretin was present in cells located in the stroma of the villi or was derived from the villous epithelial cell.

\section{Electron Microscopy}

Ultrastructural surveys of the intestinal mucosa in various species were made by Vassallo, Solcia, and Capella(1969), by Capella, Solcia, and Vassallo(1969), and by Solcia, Vassallo, and Capella (1970). These resulted in the suggestion that one of the two-or possibly three-types of endocrine, non-enterochromaffin (non-EC) cells present in the small intestine must be responsible for the production of secretin. The cell which was considered, on the basis of its restricted localization, to be the most likely candi- 
date contained small secretion granules with an average diameter of $200 \mathrm{~nm}$. It was called the $S$ (for small) cell in contradistinction to the other predominant cell $(\mathrm{L})$ which had larger granules. The $\mathrm{S}$ cell is apparently the same as the 'A-like' or type IIc cell, found by Forssmann (1970) to be the predominant endocrine cell in the duodenum of dog, cat, and rat. A cell with similar characteristics was identified in human duodenum by Pearse, Coulling, Weavers, and Friesen (1970). A cell with large $(300 \mathrm{~nm})$, homogeneous but poorly osmiophilic granules was found in duodenum of several species by Solcia et al (1970); this was named the X cell.

\section{Material and Methods}

Dogs between 2 and 9 months old were used. Following intraperitoneal injection of nembutal, samples of mucosa were taken from fundus, pylorus, duodenum, jejunum, and ileum. Small pieces from each of these regions were processed, in a variety of different ways, for the various procedures outlined below.

\section{IMMUNOFLUORESCENCE}

Small samples were fixed at $4^{\circ}$ in $2 \%$ carbodiimide (Kendall, Polak, and Pearse, 1971; Polak, Bloom, Coulling, and Pearse, 1971) for 24 hours, then washed in $30 \%$ sucrose phosphate-buffered saline (PBS) and subsequently quenched in cold $\left(-165^{\circ} \mathrm{C}\right)$ Arcton (Freon) 22, and cryostat sections were prepared. All sections were cut at $5 \mu \mathrm{m}$ and processed by an indirect immunofluorescence technique (Coons, Leduc, and Connolly, 1955).

\section{ANTISERA}

Pure porcine secretin was coupled to guinea-pig serum albumin by 1-ethyl-3-(3-dimethylaminopropyl) carbodiimide hydrochloride (Sigma), according to the technique described by Young, Lazarus, Chisholme, and Atkinson (1968). This was injected into two hybrid rabbits. Control rabbits also received several injections of guinea-pig albumin treated with carbodiimide and sera from all animals were harvested after several months. The globulin fraction was obtained by cold precipitation with ammonium sulphate (Nairn, 1969). Fluorescein-labelled goat anti-rabbit serum was obtained commercially (Hyland).

\section{CONTROLS}

The following controls were used: (1) anti-secretin antibodies with added excess pure porcine secretin followed by fluorescein-labelled goat anti-rabbit antiserum; (2) normal rabbit globulin, followed by the second layer; (3) rabbit anti-human calcitonin and anti-porcine glucagon antibodies, followed by the second layer; (4) fluorescein-labelled goat antirabbit antiserum.

\section{OPTICAL MICROSCOPY}

Small blocks of mucosa were taken from each of the regions already described and treated in the following ways.

After fixation in $6 \%$ glutaraldehyde in $0.1 \mathrm{M}$

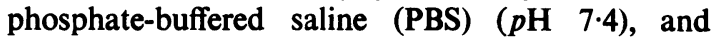
paraffin embedding, $5 \mu \mathrm{m}$ sections were processed by the Masson-Hamperl (argentaffin) method (Pearse, 1960), Lillie's xanthydrol method (Solcia, Capella, and Vassallo, 1969), and McConnaill's lead haematoxylin method (Solcia et al, 1969).

After fixation in Bouin's fluid, and paraffin embedding, $5 \mu \mathrm{m}$ sections were processed by a modified Grimelius technique (De Grandi, 1970) and by the oxidized phosphotungstic acid haematoxylin method (PTAH).

After carbodiimide fixation, and the immunofluorescence procedure, sections were viewed by dark-field microscopy or post-fixed in $6 \%$ glutaraldehyde in PBS and restained by lead haematoxylin, the Masson-Hamperl silver impregnation, or oxidized PTAH.

Photomicrographs were taken on Ilford FP4 film (for immunofluorescence) or on Pan F (other methods).

\section{ELECTRON MICROSCOPY}

Small pieces of tissue, from duodenal mucosa only, were processed immediately on removal from the animal. (This region has been shown, by modern assay techniques, to contain the highest levels of secretin.)

Samples were fixed in $3 \%$ glutaraldehyde in $0.1 \mathrm{M}$ phosphate buffer $\left(p \mathrm{H} \mathrm{7.6)}\right.$ for two hours at $4^{\circ} \mathrm{C}$. Excess fixative was removed from the blocks by repeated washing in $0.1 \mathrm{M}$ phosphate buffer containing $0 \cdot 1 \%$ sucrose. Following fixation the blocks were dehydrated in an ascending ethanol series, taken through epoxy-propane, and finally embedded in Araldite CY 212.

Other samples, after the primary fixation described above, were post-fixed in Millonig's (1962) osmium tetroxide at $4^{\circ} \mathrm{C}$ for two hours.

Sections were stained by lead citrate and uranyl acetate and viewed through an AEI EM6B electron microscope.

\section{Results}

\section{IMMUNOFLUORESCENCE}

Cells showing specific secretin fluorescence were very numerous in the duodenum, occasionally present in the jejunum, and very rare in the pyloric 


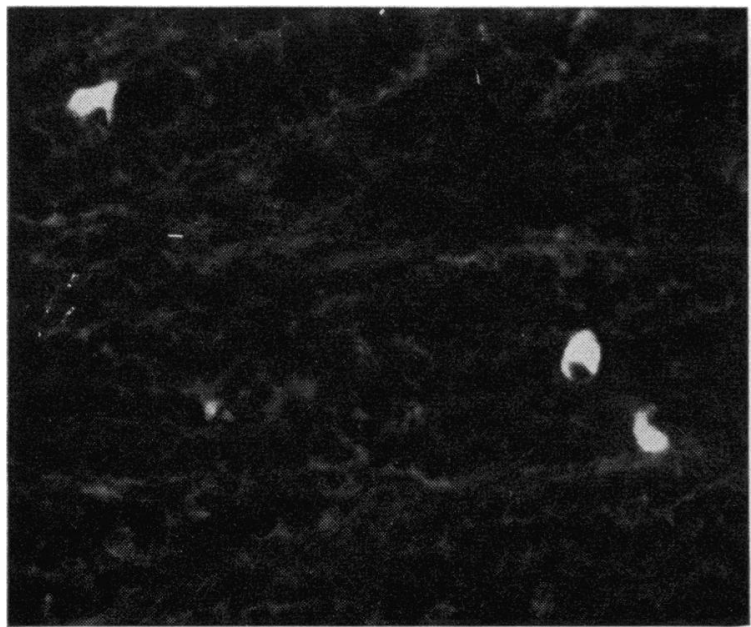

Fig. 1 Canine duodenum. CDI-fixed cryostat section. Indirect immunofluorescence technique with anti-porcine secretin. The hormone is present in three $(S)$ cells situated in the transitional zone of the mucosa $(\times 989)$.

mucosa. They were situated mostly in the transitional zone of the duodenal mucosa. (This is the region composing the base of the villi and the upper portions of the crypts.)

The secretin cells were pyramidal in shape and their hormone storage product was mainly concentrated on the side of the cell facing the basement membrane (Fig. 1), although it was often present all around the nucleus. In many instances the cell processes were observed to make contact with the lumen.

Control sections treated with anti-porcine glucagon showed specific enteroglucagon (EG) cells in all the areas studied except the pylorus. In the duodenum only a small number of cells were found. All other control sections were free from specific (fluorescein) fluorescence.

\section{COMPARATIVE CYTOCHEMISTRY}

The secretin (S) cells showed the following characteristics: (1) strongly positive staining with lead haematoxylin; (2) argyrophilia, but not argentaffinity; (3) strongly positive staining with oxidized PTAH; (4) strong luminosity (dark field) in CDIfixed sections; (5) negative xanthydrol reaction for indoles (tryptophan); (6) negative $o$-phthalaldehyde staining.

In order to identify the cells showing specific secretin immunofluorescence, in terms of cytochemical and staining characteristics, pairs of reactions or tests were applied to single sections.

Immunofluorescence sections, post-fixed in $6 \%$ glutaraldehyde for 30 minutes, were washed and
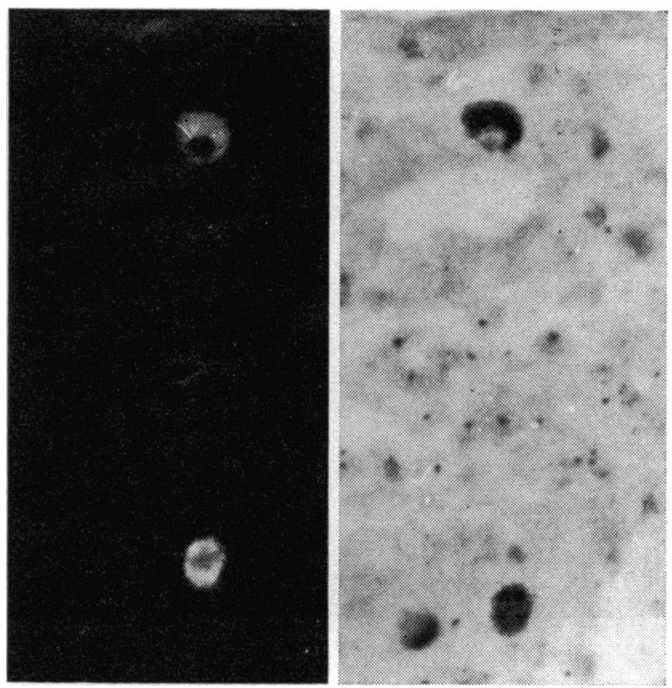

Fig. 2 Two immunofluorescent $S$ cells seen on the left have subsequently been stained with lead haematoxylin (right). A third cell, positive with this second method, contains no secretin and cannot be an $X$ cell since these do not stain; it must therefore be either EC or EG $(\times 1,108)$.

then stained with lead haematoxylin. The results are shown in Figure 2. It will be observed that the two immunofluorescent $S$ cells stain strongly. A third cell, also strongly stained, contains no secretin.

Immunofluorescence sections were examined by dark field microscopy. The results are shown in Figure 3. Specific immunofluorescence and luminosity are present in the same cell.

Immunofluorescence sections, post-fixed in $6 \%$ glutaraldehyde, were washed and then stained by the Masson-Hamperl procedure. The $\mathrm{S}$ cells were non-argentaffin. (EC cells were strongly positive.)

Similar sections were reacted for tryptophan by the xanthydrol method. The $\mathbf{S}$ cells were negative. (EG cells were positive.)

After application of the modified Grimelius technique the $\mathbf{S}$ cells exhibited argyrophilia.

With the oxidized PTAH method the $S$ cells stained blue grey.

These results indicate that the $S$ cells are distinguishable from both EC and EG cells, the latter having been identified with the $L$ cells of the Wiesbaden agreement by Polak et al (1971). They are distinguishable from the $X$ cell by its negative reaction with lead haematoxylin.

\section{ELECTRON MICROSCOPY}

In addition to the easily identifiable EC cells we were able to show, in the duodenum, the three 

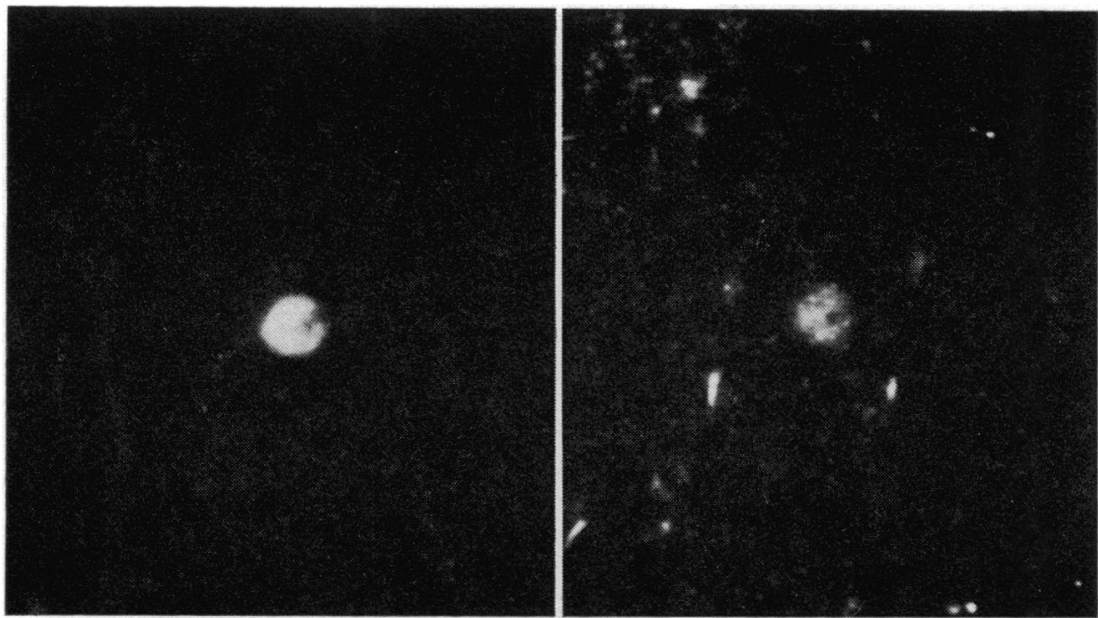

Fig. 3 A single immunofluorescent $S$ cell, seen on the left, is subsequently viewed by dark field microscopy (right). Its contained granules are refractile $(\times 1,376)$.

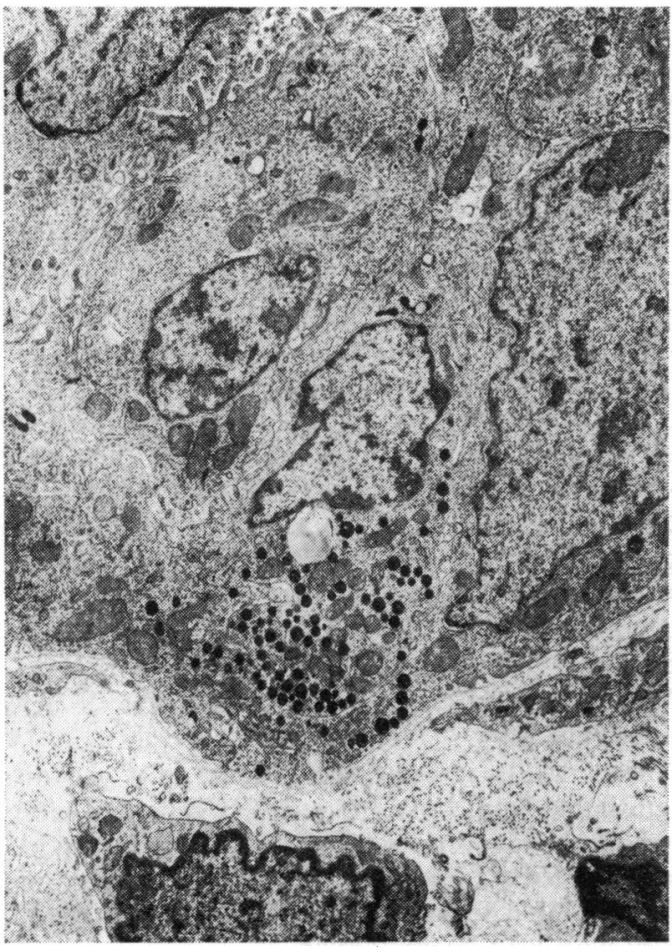

Fig. 4 Canine duodenum. Glutaraldehyde-osmium fixed tissue, counterstained with lead citrate and uranyl acetate. The tissue shows a characteristic $S$ cell containing small granules (diameter 100-150 $\mathrm{nm})(\times 6,300)$. expected additional endocrine cell types $(\mathrm{L}, \mathrm{S}$, and $\mathrm{X})$, using these terms in a purely ultrastructural sense. The predominant $S$ cell (ultrastructural criteria) (Fig. 4), was identified with the predominant $\mathrm{S}$ cell (immunofluorescence).

\section{Discussion}

Evidence has been accumulating, in the past few years, that the gastrointestinal tract is a multiendocrine organ of the first rank, certainly the largest and probably the most important endocrine organ in the body. It contains at least eight distinct members of the APUD series of endocrine polypeptide cells (Pearse, 1968, 1969 and 1971) of which three have now been identified as the source of three of the known gastrointestinal hormones. These are the gastrin-secreting $G$ cell, the enteroglucagonsecreting EG cell, and (now) the secretin-secreting $S$ cell.

Gastrin was first localized by McGuigan (1968) in the $\mathbf{G}$ cells of porcine and human stomach, so named by Solcia, Vassallo, and Sampietro (1967) on the basis of their distribution and staining characteristics. McGuigan's observations were confirmed by Bussolati and Pearse (1970) for the porcine antrum and by Pearse and Bussolati (1970) for human stomach.

Enteroglucagon was localized by Polak et al (1971) in the EG cells of the fundic and jejunal mucosa of the dog. In this paper secretin has been identified in 
the $S$ cells confirming, once more, the value of immunofluorescence in determining the nature and distribution of polypeptide hormone (APUD) cells in the gastrointestinal tract. The identification of the ultrastructural $\mathbf{S}$ cell as the site of secretin storage was based, positively, on comparisons between the distribution of $\mathbf{S}$ cells and immunofluorescent secretin cells. Both were practically restricted to the transitional zone of the duodenal mucosa. From the negative point of view, it was not necessary to eliminate the more widely distributed $L$ cell as the source of secretin since this cell (as the A cell) is present in the fundus of the stomach where secretin is lacking. Elimination of the EC cell was not required at the electron microscope level since the secretin-containing cell is not argentaffin. Finally, out of the four available cell types, elimination of the $\mathrm{X}$ cell was not required at the electron microscope level since this cell does not stain with lead haematoxylin whereas the secretin-containing cell does so. Thus, while an absolute identification of secretin with the $S$ cell was made only at optical microscope level, presumptive evidence allows one to make the same conclusions at the electron microscope level.

The complete identification of polypeptide hormone-producing cells, with the individual cell types shown by ultrastructural studies, requires the successful application of immunoelectron cytochemical methods. The application of these to the gastrointestinal tract, by several independent groups of workers, has resulted, so far, in a failure to produce interpretable results.

In view of the close relationship of porcine secretin to porcine glucagon (Weinstein, 1968; Mutt et al, 1970) the total absence of cross reactivity between anti-secretin antibody and the EG cells and between anti-glucagon antibody and the $S$ cells must indicate either totally different antigenic sequences or conformational differences in a common amino-acid sequence. Of these two possibilities the former seems the most likely.

Some comments on the comparative cytochemical tests may be necessary. The oxidized PTAH method has been used as a simple and selective stain for pancreatic $\alpha_{2}$ cell granules and linked (Cavallero, Solcia, Vassallo, Capella, and Bussolati, 1970) to the relatively basic nature of glucagon. We found (Polak et al, 1971) that the EG cell granules stained positively and it is perhaps not surprising that the $\mathrm{S}$ cell granules also stain by this method.

Pancreatic $\alpha_{2}$ cell granules, EG granules, and S granules all show argyrophilia in paraffin sections treated by the Grimelius silver method. Cavallero et al (1970) and Solcia et al (1970) have carried out a modified Grimelius procedure at the electron micro- scope level. Both $\alpha_{2}$ and $S$ granules showed deposition of silver grains on the outer rim of the granules and not on, or in, the dense osmiophilic central core. This finding suggests that argyrophilia may be a property of the lipoprotein envelope of the granules and unrelated to their actual content (ie, useless for distinction of one hormone from another).

All three granules $\left(\alpha_{2}, E G, S\right)$ show dark field luminosity, which merely reflects a refractive index difference between them and their environment (ie, useless for distinction of one hormone from another).

All three granules stain positively with lead haematoxylin. This method probably depends more on the acidic nature of the lipoprotein envelope and of any lipoprotein matrix present in the granule than on the precise composition of the polypeptide in the latter (ie, useless for distinction between one hormone and another).

Pancreatic $\alpha_{2}$ cells and EG cells are positive by the xanthydrol method for tryptophan; the $S$ cells are negative. This is a significant difference which reflects the absence of tryptophan from secretin. If this hormone is stored in the form of a precursor the tryptophan content of this must also be minimal.

This work has been carried out with the help of a grant from the Wellcome Trust. It was made possible by a generous gift of pure porcine secretin from $\mathrm{Dr}$ V. Mutt, to whom we are suitably grateful.

\section{References}

Bayliss, W. M., and Starling, E. H. (1902). The mechanism of pancreatic secretion. J. Physiol. (Lond.), 28, 325-353.

Bussolati, G., and Pearse, A. G. E. (1970). Immunofluorescent localization of the gastrin-secreting $\mathbf{G}$ cells in the pyloric antrum of the pig. Histochemie, 21, 1-4.

Capella, C., Solcia, E., and Vassallo, G. (1969). Identification of six types of endocrine cells in the gastrointestinal mucosa of the rabbit. Arch. histol. jap., 30, 479-495.

Cavallero, C., Solcia, E., Vassallo, G., Capella, C., and Bussolati, G. (1970). Cytology, cytochemistry and ultrastructure of glucagonsecreting cells. Acta diabetol. Lat., 7, 542-555.

Coons, A. H., Leduc, E. H., and Connolly, J. M. (1955). Studies on antibody production. I: Method for the histochemical demonstration of specific antibody and its application to a study of the hyperimmune rabbit. J. exp. Med., 102, 49-60.

Cordier, R. (1926). Recherches morphologiques et expérimentales sur la cellule chromo-argentaffine de l'epithélium intestinal des vertébrés. Arch. Biol. (Liège), 36, 427-463.

De Grandi, P. (1970). The routine demonstration of $G$ cells in human and animal thyroid glands. Virchows Arch. Zellpath., 6 137150.

Forssmann, W. G. (1970). Ultrastructure of hormone-producing cells of the upper gastrointestinal tract. In Origin, Chemistry, Physiology and Pathophysiology of the Gastrointestinal Hormones, edited by W. Creutzfeldt, pp. 31-70.

Friedman, M. H. E., and King. E. (1950). Unpublished data, cited by Thomas (1950).

Gillman, J. (1942). The structure of the basal granular cell (argentaffine) in the human (Bantu) aliment ary canal with spicial reference to the anti-anaemic factor. S. Afr. J. med. Sci., 7, 144-159.

Grossman, M. I. (1958). The physiology of secretin. Vitam. u. Horm., 16, 179-203.

Jorpes, J. E., and Mutt, V. (1961a). The gastrointestinal hormones, secretin and cholecystokinin-pancreozymin. Ann. intern. Med., 55. 395-405. 
Jorpes, J. E., and Mutt, V. (1961b). On the biological activity and amino-acid composition of secretin. Acta chem. scand., 15, 1790-1791.

Kendall, P. A., Polak, Julia, M., and Pearse, A. G. E. (1971). Carbodiimide fixation for immunohistochemistry: observations on the fixation of polypeptide hormones. Experientia (Basel), in press.

Komarov, S. A. (1942). Studies on gastrin. II. Physiological properties of the specific gastric secretagogue of the pyloric mucous membrane. Rev. Canad. Biol., 1, 377-401.

Krawitt, E. L., Zimmerman, G. R., and Clifton, J. A. (1966). Location of secretin in dog duodenal mucosa. Amer. J. Physiol., 211, 935-938.

McGuigan, J. E. (1968). Gastric mucosal intracellular localization of gastrin by immunofluorescence. Gastroenterology, 55, 315-327.

Mellanby, J. (1926). The mechanism of pancreatic secretion. Lancet, 2, 215-218.

Millonig, G. (1962). Further observations on a phosphate buffer for osmium solutions in fixation. In Proceedings 5th International Congress for Electromicroscopy, edited by Sydney S. Breese, Jr. Academic Press, New York.

Munch-Petersen, J., Rönnow, G., and Uvnäs, B. (1944). Further studies on the gastric secretory excitants from the pyloric mucosa. Acta physiol. scand., 7, 289-302.

Mutt, V., Jorpes, J. E., and Magnusson, S. (1970). Structure of porcine secretin: the amino acid sequence. Europ. J. Biochem., 15, 513-519.

Mutt, V., Magnusson, S., Jorpes, J. E., and Dahl, E. (1965). Structure of porcine secretin. I. Degradation with trypsin and thrombin. Sequence of the tryptic peptides. The C-terminal residue. Biochemistry, 4, 2358-2362.

Nairn. R. C. (1969). Fluorescent Protein Tracing. Livingstone, Edinburgh and London.

Parat, M. (1924). Contribution à l'histo-physiologie des organes digestifes de l'embryon. L'apparition corrélative de la cellule de Kultschitzky et de la sécrétine chez l'embryon. C.R. Soc. Biol. (Paris), 90, 1023-1024.

Pearse, A. G. E. (1960). Histochemistry, Theoretical and Applied, 2nd ed. Churchill, London.

Pearse, A. G. E. (1968). Common cytochemical and ultrastructural characteristics of cells producing polypeptide hormones (The APUD Series) and their relevance to thyroid and ultimobranchial G cells and calcitonin. Proc. roy. Soc. B., 170, 71-80.
Pearse, A. G. E. (1969). The cytochemistry and ultrastructure of polypeptide hormone-producing cells of the APUD series and the embryologic, physiologic and pathologic implications of the concept. J. Histochem. Cytochem., 17, 303-313.

Pearse, A. G. E. (1971). The endocrine polypeptide cells of the APUD series (structural and functional correlations). Mem. Soc. Endocr., no. 19, pp. 543-556.

Pearse, A. G. E., and Bussolati, G. (1970). Immunofluorescence studies of the distribution of gastrin cells in different clinical states. Gut, 11, 646-648.

Pearse, A. G. E., Coulling, I. Weavers, B., and Friesen, S. (1970). The endocrine polypeptide cells of the human stomach, duodenum and jejunum. Gut, 11, 649-658.

Polak, J. M., Bloom, S., Coolling, I., and Pearse, A. G. E. (1971). Immunofluorescent localization of enteroglucagon cells in the gastrointestinal tract of the dog. Gut, 12, 311-318.

Solcia, E., Capella, C., and Vassallo, G. (1969). Lead haematoxylin as a stain for endocrine cells. Histochemie, 20, 116-126.

Solcia, E., Vassallo, G., and Capella, C. (1969). Studies on the G cells of the pyloric mucosa, the probable site of gastrin secretion. Gut, 10, 379-388.

Solcia, E., Vassallo, G. and Capella, C. (1970). Cytology and cytochemistry of hormone producing cells of the upper gastrointestinal tract. In Origin, Chemistry, Physiology, and Pathophysiology of the Gastrointestinal Hormones, edited by W. Creutzfeldt, pp. 3-29.

Solcia, E., Vassallo, G., and Sampietro, R. (1967). Endocrine cells in the antro pyloric mucosa of the stomach. $Z$. Zellforsch., 81, 474-486.

Thomas, J. E. (1950). The External Secretion of the Pancreas. Thomas, Springfield, Illinois.

Vassallo, G., Solcia, E., and Capella, C. (1969). Light and E.M. identification of several types of endocrine cells in the gastrointestinal mucosa of the cat.Z. Zellforsch., 98, 333-356.

Weinstein, B. (1968). On the relationship between glucagon and secretin. Experientia (Basel), 24, 406-408.

Wermel, E. M., and Kacharova, E. A. (1948). The role of the basal granular cells of the mucosa of the small intestine in the production of secretin. Anat. Rec., 101, 595-604.

Young, J. D., Lazarus, L., Chisholm, D. J., and Atkinson, F. F. V. (1968). Radioimmunoassay of secretin in human serum. $J$. nucl. Med., 9, 641-642. 